\title{
КНИЖЕВНОСТ, МУЗИЧКА И ЛИКОВНА КУЛТУРА У ФУНКЦИЈИ РАЗВОЈА ЕСТЕТСКИХ СПОСОБНОСТИ УЧЕНИКА - ТРАНСФЕРЗАЛНО ИСТРАЖИВАњЕ
}

\author{
Јелена Максимовић ${ }^{1}$, Јелена Османовић, Тамара Вукић \\ Универзитет у Нишу, Филозофски факултет, Департман за педагогију
}

\begin{abstract}
Ancmpaкm: Естетске способности се огледају у препознавању, доживљавању и стварању лепог, а развој естетских способности ученика важан је задатак школе, будући да су од великог значаја за испуњен живот сваког појединца и хуманизовање његове природе, за експресију емоција и унутрашњих доживљаја. У раду су приказане могућности за развој естетских способности ученика путем садржаја из књижевности, музичке културе и ликовне културе, као и резултати истраживања чији је циљ био сазнати како ученици доживљавају садржаје из поменутих предмета, односно да ли ови садржаји доприносе развоју њихових естетстких способности. У истраживању је учествовало 104 ученика са територије града Књажевца, а добијени резултати су показали да је код ученика развијена способност за препознавање естетских елемената, али када је реч о способностима за доживљавање и стварање лепог, резултати показују да садржаји из књижевности, музичке и ликовне културе не подстичу естетска осећања и естетске доживљаје, као ни потребу за преношењем естетских елемената у свакодневни живот. Другим речима, све три способности: препознавање, доживљавање, стварање „лепог“ су присутне тек код појединих ученика.
\end{abstract}

Кључне речи: естетско васпитање, естетске способности ученика, књижевност, музичка култура, ликовна култура

\section{Увод}

Препознавање, доживљавање и стварање лепог представљају естетске способности које заузимају централно место нашег истраживања. Полазећи од питања на који начин, посредством којих садржаја се развијају естетске способности ученика, логичан закључак је да су то садржаји из књижевности, ликовне и музичке културе. Било да је реч о бајци, басни, приповеци или неком

\footnotetext{
${ }^{1}$ jelena.maksimovic@ $@$ filfak.ni.ac.rs
} 
другом књижевном делу, о нотним записима, композицијама или уметничким делима у виду слика, скулптура, графике и др., садржаји из књижевности, музичке и ликовне културе обилују естетским елементима, а задтак школе је да могућности које пружају ови садржаји искористи за развој естетских способности ученика.

Уз претпоставку да су предмети које смо одабрали адекватни за развијање естетских способности, настојали смо да утврдимо да ли ученици препознају оно „лепо“ у садржајима, да ли они код њих буде одговарајуће доживљаје и осећања, као и да ли их подстичу да то „лепо“ пренесу у свој свакодневни живот, креирајући своја мала уметничка дела. Овим истраживањем желимо да истакнемо значај развоја естетских способности ученика кроз наставне садржаје, јер су оне појединцу неопходне како би могао да разуме друге људе, живот, свет око себе, али и самог себе у том свету.

\section{1. Теоријски приступ проблему истраживања}

\section{Естетско васпитање и развој естетских способности ученика}

Основна категорија естетског васпитања јесте лепота, односно „лепо“ (Kostov, 2013), те се у складу са тиме, естетско васпитање може дефинисати као процес оспособљавања јединке да схвата, процењује, доживљава и ствара лепо у животу, раду и уметности (Đorđević i Potkonjak, 1990), односно процес који за циљ има да код појединца развије компетенције за опажање, доживљавање и стварање лепог, као и развијање естетског односа према стварности и уметности (Stojanović, 2012).

И поред тога што је естетско образовање независно од специфичних садржаја или предмета (Plummeridge, 1999), уметничка васпитна улога у школи посебно је изражена у ликовној култури, музичкој култури, књижевности, физичком васпитању и здравственој култури. Ови садржаји ученицима пружају естетске доживљаје, основна знања, доприносе развијању умења и навика, развијајући интерес за естетско и лепо формирањем њихове естетске стваралачке снаге (Pejaković, 2016). Притом је важно истаћи да свака индивидуа има могућност за естетски развој, а самим тим и за естетско васпитање (Žunić, 2008) чији је задатак да те могућности што је могуће раније открије и развија што потпуније све до тренутка када тај развој не прерасте у саморазвој, односно самоваспитање (Đorđević i Ničković, 1991). То значи да школа у настави, посебно кроз матерњи језик, ликовну и музичку културу, као и у ваннаставним активностима има задатак да ученике упозна са светом уметности и са лепим у окружењу (Đorđević, 2008). На тај начин се, од самих почетака образовања, подстиче интересовање ученика за естетска обележја уметничког дела и њихово оспособљавање за уочавање, доживљавање, остваривање и вредновање лепог и складног (Senjan, 2017).

Развој естетских осећања и способности је неопходан како би људи могли да препознају лепоту, да у њој уживају, као и да је сами стварају (Nilüfer Süzen, 2013). То се остварује задацима естетског васпитања који обухватају: 
(1) развијање способности за уочавање и вредновање или проучавање лепог на основу стечених знања и неговање естетске културе; (2) развијање способности, потреба и навика за доживљавањем лепог; (3) развијање стваралачких диспозиција и потреба за стварањем лепог у природи, друштву, уметности, животу, раду, у односима према другима, као и према себи (Đorđević i Ničković, 1991; Đorđević i Potkonjak, 1990; Trnavac i Đorđević, 1998). Другим речима, задаци естетског васпитања морају бити усмерени на: развој естетског смисла за лепо и за пропорцију; развој естетске перцепције; доживљавање, стварање, вредновање и изражавање лепог; развој односа према природи и према лепом у интерперсоналним односима (Denac, 2014). У складу са тиме, садржаји естетског васпитања су усмерени на развој личних својстава у свим сферама способности: (1) когнитивном - запажање, уочавање, разумевање и вредновање лепог; (2) емоционалном - осећање и доживљавање лепог; (3) просторно-спацијалном - остваривање или стварање лепог, уређивање себе и околине (Suzić, 2005).

Задаци естетског васпитања се, према претпоставци ауторке Бојовић (2010), могу успешно реализовати путем уџбеника и приручника за српски језик, музичку и ликовну културу.

Српски језик и књижевност. Основни циљ наставе српског језика и књижевности је да ученике оспособи за нормативну употребу језика, да изгради њихову потребу за читањем, као и способност да приликом читања достигну естетски доживљај и висок ниво разумевања (Stevanović i Dimitrijević, 2013). Сви елементи књижевног дела морају бити прожети естетским, док дидактичке и васпитне импликације садржане у делу морају бити у функцији естетског (Ristić, 2007). При испитивању постојећег стања, када је реч о бајкама, као књижевним делима која подстичу машту ученика, изазивају снажне емоције и развијају естетски укус, ауторка Стојановић (2012) је утврдила да су естетски укус ученика и њихове естетске компетенције недовољно развијени. Према резултатима истраживања спроведеног у Турској у вези са естетским вредностима случајно одабраних песама и прича које се обрађују на часовима турског језика и књижевности (Pilav, 2016), утврђено је да многе не задовољавају естетске критеријуме, иако садрже већи број естетских елемената.

Музичка култура. Развој естетских способности ученика у области музичке културе се огледа у развоју музичких диспозиција ученика и стварању навика за активно бављење музиком укључујући слушање музике, певање и свирање. Код ученика је потребно развити способност да осети карактер и расположење музичког дела, да разуме музички израз и доживи емоционални однос према музичком делу, да га опажа, упоређује и вреднује, али и да стваpa музику (Đorđević, 2008). Међутим, како пише Ројко (2012) музичка култура пружа мало могућности за прави естетски развој, с обзиром на то да школи недостају неопходни услови, првенствено довољан број часова, за реализацију музичких активности деце. Осим тога, у неким наставним подручјима, као што су описмењавање и стицање знања из области музике естетстко васпитање се не остварује, а у подручјима у којима би се и могло остваривати (певање, свирање, стваралаштво) такође га нема, јер те активности не дотичу онај ниво 
који би се могао означити као естетски. Једино естетско подручје је слушање музике које је, због ограниченог времена, због веровања у потребу за активним музицирањем, због ставова и образованости наставника, због неадекватне опремљености школа, маргинализовано, те преостаје мало простора и времена за естетско васпитање.

Ликовна култура. Циљ ликовне културе би, како наводи Милутиновић (2015) требало да буде усмерен на развој стваралачких способности и естетског процењивања, а програм естетског образовања би требало да обухвати: перцепцију визуелног односа, продукцију уметничког дела, познавање и разумевање уметничких објеката и процену уметничких дела. Неки од задатака ликовне културе са елементима естетског васпитања и образовања истакнутих у наставним програмима за сваки разред основног образовања ${ }^{2}$ су: ликовно изражавање ученика; стварање услова за развијање свести о потреби чувања природне и културне околине, те активног учествовања у квалитетном естетском и просторном уређењу животне околине; подстицање интересовања и стварање потребе за посећивањем музеја, изложби, као и за чувањем културних добара и естетског изгледа средине; посматрање и естетско доживљавање дела ликовних уметности; усвајање естетских критеријума за креативно мишљење; активно естетско унапређивање своје околине; развијање смисла за естетске ликовне и визуелне вредности и др.

Било да је реч о бајци, басни, приповеци или неком другом књижевном делу, о нотним записима, односно композицијама или уметничким делима у виду слика, скулптура, графике и др., садржаји из књижевности, музичке и ликовне културе се чине погодним за развој естетских способности ученика. Према резултатима истраживања ауторке Бојовић (2010), садржаји поменутих предмета подстичу развој естетских способности, онда када посматрамо сваку способност посебно. Највише се активирају способности доживљавања и разумевања лепог, док се способности опажања и стварања лепог мање подстичу. С обзиром на то да се естетске компетенције надограђују једна на другу, ауторка поставља питање: „Како можемо инсистирати на доживљајној компоненти неког текста, позоришне представе или уметничке слике, ако нисмо ученика претходно оспособили да уочава естетске елементе?““ (Бојовић, 2010: 255).

\section{2. Методолошки приступ проблему истраживања}

Циљ и задащи. Циљ рада је да сазнамо како ученици доживљавају садржаје из књижевности, музичке и ликовне културе, односно да ли поменути садржаји доприносе развоју њихових естетских способности. Задаци су: (1) утврдити да ли садржаји из књижевности доприносе развоју способности за опажање, доживљавање и стварање лепог; (2) утврдити да ли садржаји из музичке културе доприносе развоју способности за опажање, доживљавање и стварање лепог;

\footnotetext{
${ }^{2}$ доступно на: http://www.cerez.org.rs/dokumenta/
} 
(3) утврдити да ли садржаји из ликовне културе доприносе развоју способности за опажање, доживљавање и стварање лепог.

Инструмент. Примењена је скала процене Ликертовог типа РЕСУ (Развој естетских способности ученика), којом испитујемо ставове ученика о садржајима из књижевности, музичке културе и ликовне културе у контексту развоја њихових естетских способности. Њихов задатак био је да изразре степен слагања са понуђеним тврдњама одабиром једне од пет могућности: уопште се не слажем, не слажем се, нити се слажем нити се не слажем, слажем се и у потпуности се слажем. Скала обухвата 22 тврдње и посебно је конструисана за потребе истраживања.

Узорак. Узорак испитаника обухвата ученике 7. и 8. разреда основне школе „Дубрава” у Књажевцу, као и ученике 1. и 2. године Књажевачке гимназије. Узорак сачињавају 104 испитаника.

Табела 1. Структура испитаника с обзиром на разред

\begin{tabular}{ccc}
\hline Разред & $\mathbf{N}$ & $\%$ \\
\hline 7. и 8. разред & 52 & 50 \\
1. и 2. година & 52 & 50 \\
Укупно & 104 & 100 \\
\hline
\end{tabular}

\section{3. Анализа и интерпретација резултата истраживања}

Развој естетских способности ученика путем садржаја из кюижсевности

Књижевна дела обилују естетским елементима што представља могућност за развој естетских способности ученика. У сусрету са књижевним делом, препознавањем естетских елемената, начињен је први корак ка развоју естетских способности. Поред тога, естетско садржано у књижевном делу код ученика може подстаћи доживљај лепог и потребу да и сам/а створи нешто слично. Перцепције садржаја из књижевности из угла ученика приказане су у Табели 2.

Табела 2. Перцепције садржаја из књижевности из угла ученика

\begin{tabular}{|c|c|c|c|c|c|c|c|c|c|c|c|c|}
\hline & \multicolumn{2}{|c|}{$\begin{array}{l}\text { Уопште се } \\
\text { не слажем }\end{array}$} & \multicolumn{2}{|c|}{$\begin{array}{c}\text { Не } \\
\text { слажем } \\
\text { се }\end{array}$} & \multicolumn{2}{|c|}{$\begin{array}{l}\text { Нити се } \\
\text { слажем, } \\
\text { нити се не } \\
\text { слажем }\end{array}$} & \multicolumn{2}{|c|}{$\begin{array}{l}\text { Слажем } \\
\text { се }\end{array}$} & \multicolumn{2}{|c|}{$\begin{array}{c}\mathbf{y} \\
\text { потпуности } \\
\text { се слажем }\end{array}$} & \multirow[t]{2}{*}{$\mathbf{M}$} & \multirow[t]{2}{*}{ SD } \\
\hline & $\mathrm{N}$ & $\%$ & $\mathrm{~N}$ & $\%$ & $\mathrm{~N}$ & $\%$ & $\mathrm{~N}$ & $\%$ & $\mathrm{~N}$ & $\%$ & & \\
\hline $\begin{array}{l}\text { Свако књижевно дело носи у } \\
\text { себи неку поруку }\end{array}$ & 6 & 5.8 & 5 & 4.8 & 9 & 8.7 & 34 & 32.7 & 50 & 48.1 & 4.12 & 1.12 \\
\hline $\begin{array}{l}\text { Често пожелим да и сам/а } \\
\text { напишем књигу како бих } \\
\text { људима пренео/ла своју } \\
\text { поруку }\end{array}$ & 31 & 29.8 & 12 & 11,5 & 18 & 17.3 & 16 & 15.4 & 27 & 26 & 2.96 & 1.59 \\
\hline $\begin{array}{l}\text { Читање школских лектира } \\
\text { ме само додатно оптерећује }\end{array}$ & 22 & 21.2 & 13 & 12.5 & 23 & 22.1 & 18 & 17.3 & 28 & 26.9 & 3.16 & 1.49 \\
\hline
\end{tabular}




\begin{tabular}{|c|c|c|c|c|c|c|c|c|c|c|c|c|}
\hline $\begin{array}{l}\text { Садржаји које обрађујемо } \\
\text { из књижевности су ме } \\
\text { мотивисали да и сам/а нешто } \\
\text { напишем }\end{array}$ & 38 & 36.5 & 22 & 21.2 & 18 & 17.3 & 18 & 17.3 & 8 & 7.7 & 2.38 & 1.34 \\
\hline $\begin{array}{l}\text { Лако могу да увидим „шта је } \\
\text { писац хтео да каже“ }\end{array}$ & 4 & 3.8 & 18 & 17.3 & 34 & 32.7 & 29 & 27.9 & 19 & 18.3 & 1.39 & 1.09 \\
\hline $\begin{array}{l}\text { Када читам добру књигу } \\
\text { замишљам да се све лепе и } \\
\text { необичне ствари догађају } \\
\text { мени }\end{array}$ & 14 & 13.5 & 15 & 14.4 & 26 & 25 & 27 & 26 & 22 & 21.2 & 3.27 & 1.32 \\
\hline $\begin{array}{l}\text { Часови из књижевности } \\
\text { су ме подстакли на то да } \\
\text { постанем члан рецитаторске } \\
\text { секције }\end{array}$ & 59 & 56.7 & 19 & 18.3 & 16 & 15.4 & 3 & 2.9 & 7 & 6.7 & 1.85 & 1.20 \\
\hline
\end{tabular}

Добијени подаци показују да ученици увиђају да књижевна дела преносе одређене поруке (32.7\% ученика се слаже, а $48.1 \%$ се у потпуности слаже), а самим тим увиђају и значај књижевних дела и оно „лепо“што се у њима крије. У вези са тиме, код неких ученика се јавила жеља да и сами пренесу своју поруку путем књижевног дела (15.4\% са одговором слажем се и $26 \%$ са одговором у потпуности се слажем), али исти проценат се не слаже (11.5\%), односно уопште не слаже са тиме (29.8\%). Поред тога, ученици се не слажу $(21.2 \%)$ и уопште не слажу (36.5\%) да су их садржаји из књижевности мотивисали да сами нешто напишу што значи да садржаји нису утицали на развој способности ученика да и сами створе естетско дело. Такође, садржаји из књижевности нису мотивисали ученике да се укључе у рецитаторску секцију (56.7\% са одговором уопште се не слажем и $18.3 \%$ са одговором не слажем се). Када је реч о разумевању „онога што је писац хтео да каже“, највећи број ученика је дао одговор нити се слажем, нити се не слажем (32.7\%), а потом следе они који се слажу (27.9\%). Ставови ученика су подељени у вези са тврдњом Читање школских лектира ме само додатно оптерећује (највише је неодлучних $(22.1 \%)$ ), као и у случају тврдње Када читам добру књигу замишљам да се све лепе и необичне ствари догађају мени (27\% ученика дало је одговор нити се слажем нити се не слажем).

Шареноликост у одговорима ученика, односно недостатак усаглашених ставова наводи на закључак да садржаји из књижевности не остварују у потпуности своју функцију у подстицању и развоју естетских компетенција ученика, те да је препознавање, доживљавање и стварање лепог на основу подстицаја које пружају садржаји из књижевности индивидуална ствар. Узрок томе може бити недовољна заступљеност естетских елемената у садржајима из књижевности, али вероватније је да је проблем у неадекватном приступу наставника. Насупрот истраживању ауторке Стојановић (2012) које је показало да наставник не инсистира на уочавању естетских елемената у бајкама, резултати нашег истраживања показују да ученици уочавају и препознају естетске елементе у књижевним делима. Међутим, иста аналогија се може применити и на остале естетске способности, те се може претпоставити да је узрок томе што ученици немају развијене способности доживљавања и стварања лепог недовољна ан- 
гажованост наставника у процесу побуђивања естетског доживљаја ученика и њиховог мотивисања да, на основу естетског које су препознали и доживели, и сами створе нешто лепо.

Табела 3. Разлике у перцепцијама садржаја из књижевности из угла ученика

\begin{tabular}{|c|c|c|c|c|c|c|}
\hline & Разред & $\mathbf{M}$ & SD & t-test & df & $\mathbf{p}$ \\
\hline \multirow{3}{*}{$\begin{array}{c}\text { Садржаји које обрађујемо из } \\
\text { књижевности су ме мотивисали да и } \\
\text { сам/а нешто напишем }\end{array}$} & 7. и 8. раз. & 2.65 & 1.33 & \multirow{3}{*}{2.08} & \multirow{3}{*}{102} & \multirow{3}{*}{.04} \\
\hline & & & & & & \\
\hline & 1. и 2. год. & 2.12 & 1.32 & & & \\
\hline
\end{tabular}

Израчунавањем t-теста долазимо до закључка да се статистички значајна разлика у одговорима испитаника појављује код тврдње Садржаји које обрађујемо из кьижевности су ме мотивисали да и сам/а нешто напишем $(\mathrm{p}=.04 ; \mathrm{p}<.05)$. Док су ученици 1. и 2. године најчешће давали одговор не слажем се $(\mathrm{M}=2.12)$, ученици 7. и 8. разреда су показали већу неодлучност у вези са наведеном тврдњом (M=2.65). Могуће је да до ове разлике долази због веће заступљености конкурса и такмичења из области књижевности у основној школи, а да садржаји из књижевности код ученика буде заинтересованост да и сами нешто напишу и учествују на неком од њих.

Развој естетских способности ученика путем садржаја из музичке културе

Музика представља један од најзначајнијих извора естетских елемената. Она је саставни део људских живота, пружајући пријатност и уживање. Музички садржаји могу да утичу на развој естетских способности, односно на препознавање, доживљаваље и стварање лепог. Управо зато музичка култура адекватним садржајима би требало да утиче на младе људе како би им омогућила развијање ових способности. Перцепције садржаја из музичке културе из угла ученика приказане су у Табели 4.

Табела 4. Перцепције садржаја из музичке културе из угла ученика

\begin{tabular}{|c|c|c|c|c|c|c|c|c|c|c|c|c|}
\hline & \multicolumn{2}{|c|}{$\begin{array}{c}\text { Уопште се не } \\
\text { слажем }\end{array}$} & \multicolumn{2}{|c|}{ Не слажем се } & \multicolumn{2}{|c|}{$\begin{array}{c}\text { Нити се } \\
\text { слажем, } \\
\text { нити се не } \\
\text { слажем }\end{array}$} & \multicolumn{2}{|c|}{ Слажем се } & \multicolumn{2}{|c|}{$\begin{array}{c}\mathbf{y} \\
\text { потпуности } \\
\text { се слажем }\end{array}$} & \multirow[t]{2}{*}{$\mathbf{M}$} & \multirow[t]{2}{*}{ SD } \\
\hline & $\mathrm{N}$ & $\%$ & $\mathrm{~N}$ & $\%$ & $\mathrm{~N}$ & $\%$ & $\mathrm{~N}$ & $\%$ & $\mathrm{~N}$ & $\%$ & & \\
\hline $\begin{array}{l}\text { Након часа музичке културе } \\
\text { пожелим да се и сам } / \text { бавим } \\
\text { компоновањем музике }\end{array}$ & 55 & 52.9 & 23 & 22.1 & 16 & 15.4 & 7 & 6,7 & 3 & 2.9 & 1.85 & 1.10 \\
\hline $\begin{array}{l}\text { Приликом слушања неке } \\
\text { композиције, вратим се } \\
\text { у стварност тек када се } \\
\text { заврши }\end{array}$ & 44 & 42.3 & 23 & 22.1 & 15 & 14.4 & 13 & 12.5 & 9 & 8.7 & 2.23 & 1.34 \\
\hline $\begin{array}{l}\text { Не видим разлику између } \\
\text { композиција које слушамо } \\
\text { на часу музичког }\end{array}$ & 37 & 35.6 & 30 & 28.8 & 21 & 20.2 & 9 & 8.7 & 7 & 6.7 & 2.22 & 1.21 \\
\hline $\begin{array}{l}\text { Ако сам лошег расположења, } \\
\text { имам навику да слушам } \\
\text { класичну музику }\end{array}$ & 51 & 49 & 21 & 20.2 & 6 & 5.8 & 16 & 15.4 & 10 & 9.6 & 2.16 & 1.42 \\
\hline $\begin{array}{l}\text { Понекад ми се толико свиди } \\
\text { нека композиција да ми је } \\
\text { мелодија данима у глави }\end{array}$ & 23 & 22.1 & 10 & 9.6 & 15 & 14.4 & 21 & 20.2 & 35 & 33.7 & 3.34 & 1.56 \\
\hline
\end{tabular}


Јелена Максимовић, Јелена Османовић, Тамара Вукић

\begin{tabular}{lcccccccccccc}
\hline $\begin{array}{l}\text { Волео/ла бих да умем да } \\
\text { свирам неки инструмент }\end{array}$ & 10 & 9.6 & 3 & 2.9 & 10 & 9.6 & 30 & 28.8 & 51 & 49 & 4.05 & 1.26 \\
\hline $\begin{array}{l}\text { Школа би требало да } \\
\text { организује одласке на } \\
\text { концерте класичне музике }\end{array}$ & 41 & 39.4 & 22 & 21.2 & 14 & 13.5 & 13 & 12.5 & 14 & 13.5 & 2.39 & 1.45 \\
\hline $\begin{array}{l}\text { Свака композиција коју смо } \\
\text { обрађивали на часу музичке } \\
\text { културе има своју ,причу“ }\end{array}$ & 18 & 17.3 & 18 & 17.3 & 26 & 25 & 21 & 20.2 & 21 & 20.2 & 3.09 & 1.37 \\
\hline $\begin{array}{l}\text { Часови музичке културе } \\
\text { су ме подстакли да се } \\
\text { пикључим хору }\end{array}$ & 64 & 61.5 & 18 & 17.3 & 6 & 5.8 & 8 & 7.7 & 8 & 7.7 & 1.83 & 1.29 \\
\hline
\end{tabular}

Према одговорима ученика, часови музичке културе их нису подстакли на бављење компоновањем (52.9\% се уопште не слаже; $22.1 \%$ се не слаже), нису код њих развили навику и потребу за слушањем класичне музике $(49 \%$ се уопште не слаже; $28.8 \%$ се не слаже), нису их подстакли да се прикључе хору (61.5\% се уопште не слаже; $17.3 \%$ се не слаже), али би волели да умеју да свирају неки инструмент (28.8\% се слаже; $49 \%$ се потпуно слаже). Ученици не сматрају да би школа требало да организује одласке на концерте класичне музике (39.4\% са одговором уопште се не слажем; $21.2 \%$ са одговором не слажем се). Они препознају разлике између композиција које слушају на часовима музичке културе (35.6\% се уопште не слаже да не види разлику, а 28.8\% се не слаже), али се приликом њиховог слушања не „искључују“ из стварности $(42.3 \%$ са одговором уопште се не слажем; $22.1 \%$ са одговором не слажем се). Међутим, они се слажу (20.2\%) и потпуно слажу (33.7\%) да им се понекад толико свиди нека музичка композиција да им је мелодија данима у глави. Ставови студената у вези са тврдњом Свака композиција коју смо обрађивали на часу музичке кулmуре има своју „причу“ су подељени (највећи проценат је неодлучан (25\%), а потом следе ученици који се слажу (20.2\%) и потпуно слажу $(20.2 \%))$.

И поред тога што ученици препознају разлику између композиција које се обрађују на часовима музичке културе и желе да и сами стварају музику компоновањем, то није довољно за закључак да су садржаји из музичке културе допринели развоју естетских способности ученика. Практичну реализацију часова музичке културе у нашој земљи карактерише певање и слушање музике, и повремени одласци на концерте класичне музике. Међутим, могло би се рећи да се ове активности спроводе више механички, без адекватног педагошког приступа наставника чији је задатак да код ученика буди естетске доживљаје и усмерава их ка преношењу музике у свој свакодневни живот, односно ка стварању лепог у овој области. Резултат тога је да ученици одлазе на концерте класичне музике да би задовољили потребне критеријуме наставника, напамет уче разлике одређених музичких праваца, композиција и стилова, без правог естстеског доживљаја. Самим тим, може се рећи да, како пише Ројко (2012) музичке активности не дотичу онај ниво који би се могао означити као естетски. Осим тога, овај аутор наводи да је остваривање естетских вредности могуће једино путем хора и оркестра, а резултати нашег истраживања показују да садржаји из музичке културе нису подстакли ученике да се прикључе хору. 
Табела 5. Разлике у перцепцијама садржаја из музичке културе из угла ученика

\begin{tabular}{|c|c|c|c|c|c|c|}
\hline & Разред & M & SD & t-test & df & $\mathbf{p}$ \\
\hline \multirow{3}{*}{$\begin{array}{l}\text { Након часа музичке културе } \\
\text { пожелим да се и сам/а бавим } \\
\text { компоновањем музике }\end{array}$} & 7. и 8. раз. & 2.10 & 1.22 & \multirow{3}{*}{2.38} & \multirow{3}{*}{93.18} & \multirow{3}{*}{0.02} \\
\hline & & & & & & \\
\hline & 1. и 2. год. & 1.60 & .89 & & & \\
\hline \multirow{3}{*}{$\begin{array}{l}\text { Приликом слушања неке } \\
\text { композиције, вратим се у } \\
\text { стварност тек када се заврши }\end{array}$} & 7. и 8. раз. & 2.73 & 1.44 & \multirow{3}{*}{4.06} & \multirow{3}{*}{92.32} & \multirow{3}{*}{.00} \\
\hline & & & & & & \\
\hline & 1. и 2. год. & 1.73 & 1.03 & & & \\
\hline \multirow{3}{*}{$\begin{array}{l}\text { Ако сам лошег расположења, } \\
\text { имам навику да слушам } \\
\text { класичну музику }\end{array}$} & 7. и 8. раз. & 2.75 & 1.60 & \multirow{3}{*}{4.60} & \multirow{3}{*}{81.28} & \multirow{3}{*}{.00} \\
\hline & & & & & & \\
\hline & 1. и 2. год. & 1.58 & .92 & & & \\
\hline \multirow{3}{*}{$\begin{array}{l}\text { Понекад ми се толико свиди } \\
\text { нека композиција да ми је } \\
\text { мелодија данима у глави }\end{array}$} & 7. и 8. раз. & 3.88 & 1.42 & \multirow{3}{*}{3.81} & \multirow{3}{*}{102} & \multirow{3}{*}{.00} \\
\hline & & & & & & \\
\hline & 1. и 2. год. & 2.79 & 1.51 & & & \\
\hline \multirow{3}{*}{$\begin{array}{l}\text { Школа би требало да организује } \\
\text { одласке на концерте класичне } \\
\text { музике }\end{array}$} & 7. и 8. раз. & 2.73 & 1.46 & \multirow{3}{*}{2.42} & \multirow{3}{*}{101.69} & \multirow{3}{*}{.02} \\
\hline & & & & & & \\
\hline & 1. и 2. год. & 2.06 & 1.38 & & & \\
\hline \multirow{3}{*}{$\begin{array}{l}\text { Свака композиција коју смо } \\
\text { обрађивали на часу музичке } \\
\text { културе има своју „причу“ }\end{array}$} & 7. и 8. раз. & 3.58 & 1.21 & \multirow{3}{*}{3.88} & \multirow{3}{*}{102} & \multirow{3}{*}{.00} \\
\hline & & & & & & \\
\hline & 1. и 2. год. & 2.60 & 1.36 & & & \\
\hline \multirow{3}{*}{$\begin{array}{l}\text { Часови музичке културе су ме } \\
\text { подстакли да се прикључим } \\
\text { хору }\end{array}$} & 7. и 8. раз. & 2.14 & 1.50 & \multirow{3}{*}{2.50} & \multirow{3}{*}{86.92} & \multirow{3}{*}{.01} \\
\hline & & & & & & \\
\hline & 1. и 2. год. & 1.52 & .96 & & & \\
\hline
\end{tabular}

Статистички значајна разлика у перцепцијама ученика с обзиром на разред утврђена је код тврдњи: Након часа музичке културе пожелим да се и сам/а бавим компоновањем музике $(\mathrm{p}=.02 ; \mathrm{p}<.05)$; Приликом слушања неке композищије, вратим се у стварност тек када се заврши ( $\mathrm{p}=.00 ; \mathrm{p}<., 05) ;$ Ако сам лошег расположења, имам навику да слушам класичну музику $(\mathrm{p}=.00 ; \mathrm{p}<.05)$; Часови музичке културе су ме подстакли да се прикључим хору $(\mathrm{p}=.01 ; \mathrm{p}<.05)$. Код ових тврдњи ученици 7. и 8. разреда су чешће давали одговор не слажем ce $(\mathrm{M}=2.10 ; \mathrm{M}=2.73 ; \mathrm{M}=2.75$ и $\mathrm{M}=2.14)$, а ученици 1. и 2. године уопште се не слажем $(\mathrm{M}=1.60 ; \mathrm{M}=1.73 ; \mathrm{M}=1.58$ и $\mathrm{M}=1.52)$. Статистички значајна разлика добијена је и у случају тврдњи: Понекад ми се толико свиди нека композиција да ми је мелодија данима у глави ( $\mathrm{p}=.00 ; \mathrm{p}<.05)$ и Свака композищија коју смо обрађивали на часу музичке културе има своју ,причу“ ( $\mathrm{p}=.00 ; \mathrm{p}<.05)$. У случају ових тврдњи, ученици 7. и 8. разреда су претежно одговарали са нити се слажем, нити се не слажем $(\mathrm{M}=3.88 ; \mathrm{M}=3.58)$, док су ученици 1. и 2. године давали одговор не слажем се $(\mathrm{M}=2.79 ; \mathrm{M}=2.60)$. Добијена вредност $\mathrm{p}=.02(\mathrm{p}<.05)$ нам указује да статистички значајна разлика у перцепцијама ученика постоји и у случају тврдње Школа би требало да организује одласке на концерте класичне музике. 
Развој естетских способности ученика путем садржаја из ликовне културе Прво што нам падне на памет када говоримо о уметности јесте сликарство. Сликарство је извор естетских доживљаја, извор разноврсних осећања која имамо у додиру са неким уметничким делом. Да бисмо видели лепоту и хармонију сваког уметничког дела, као и самог ликовног стваралаштва неопходне су нам естетске способности, а претпоставка је да се оне развијају у школи кроз наставу ликовне културе. Перцепције садржаја из ликовне културе из угла ученика приказане су у Табели 6.

Табела 6. Перцепције садржаја из ликовне културе из угла ученика

\begin{tabular}{|c|c|c|c|c|c|c|c|c|c|c|c|c|}
\hline & \multicolumn{2}{|c|}{$\begin{array}{c}\text { Уопште се не } \\
\text { слажем }\end{array}$} & \multicolumn{2}{|c|}{$\begin{array}{c}\text { Не слажем } \\
\text { се }\end{array}$} & \multicolumn{2}{|c|}{$\begin{array}{c}\text { Нити се } \\
\text { слажем, нити } \\
\text { се не слажем }\end{array}$} & \multicolumn{2}{|c|}{ Слажем се } & \multicolumn{2}{|c|}{$\begin{array}{c}\mathbf{y} \\
\text { потпуности } \\
\text { се слажем }\end{array}$} & \multirow[t]{2}{*}{ M } & \multirow[t]{2}{*}{ SD } \\
\hline & $\mathrm{N}$ & $\%$ & $\mathrm{~N}$ & $\%$ & $\mathrm{~N}$ & $\%$ & $\mathrm{~N}$ & $\%$ & $\mathrm{~N}$ & $\%$ & & \\
\hline $\begin{array}{l}\text { У сваком ликовном делу } \\
\text { могу да препознам „поруку“ } \\
\text { коју је сликар желео да } \\
\text { пренесе }\end{array}$ & 27 & 26 & 25 & 24 & 28 & 26.9 & 15 & 14.4 & 9 & 8.7 & 2.56 & 1.26 \\
\hline $\begin{array}{l}\text { Часови ликовне културе } \\
\text { ме мотивишу да стварам } \\
\text { сопствена уметничка дела }\end{array}$ & 34 & 32.7 & 15 & 14.4 & 26 & 25 & 15 & 14.4 & 14 & 13.5 & 2.62 & 1.42 \\
\hline $\begin{array}{l}\text { Садржаји из ликовне } \\
\text { културе ми помажу да } \\
\text { препознам лепоту у } \\
\text { различитим предметима }\end{array}$ & 20 & 19.2 & 21 & 20.2 & 22 & 21.2 & 25 & 24 & 16 & 15.4 & 2.96 & 1.36 \\
\hline $\begin{array}{l}\text { Часови ликовне културе су } \\
\text { непотребни за живот }\end{array}$ & 38 & 36.5 & 22 & 21.2 & 22 & 21.2 & 12 & 11.5 & 10 & 9.6 & 2.36 & 1.34 \\
\hline $\begin{array}{l}\text { Свако уметничко дело је } \\
\text { посебно и необично }\end{array}$ & 5 & 4.8 & 8 & 7.7 & 18 & 17.3 & 33 & 31.7 & 40 & 38.5 & 3.91 & 1.14 \\
\hline $\begin{array}{l}\text { Када посматрам неко } \\
\text { уметничко дело замишљам } \\
\text { како би било лепо да и сам/а } \\
\text { створим нешто слично }\end{array}$ & 15 & 14.4 & 17 & 16.3 & 26 & 25 & 21 & 20.2 & 25 & 24 & 3.23 & 1.37 \\
\hline
\end{tabular}

Добијени подаци показују да ученици сматрају да су часови ликовне културе потребни за живот (36.5\% се уопште не слаже да су непотребни; $21.2 \%$ се не слаже). Они препознају да је свако уметничко дело посебно и необично (31.7\% са одговором слажем се; $38.5 \%$ са одговором у потпуности се слажем), али када је реч о часовима ликовне културе као извор мотивације да и сами створе неко уметничко дело, мишљења ученика су подељена. То видимо у случају тврдњи: Часови ликовне културе ме мотивишу да стварам сопствена уметничка дела са којом се уопште не слаже $32.7 \%$ ученика, а потом следе они који су неодлучни (25\%) и Када посматрам неко уметничко дело замишљам како би било лепо да и сам/а створим нешто слично у вези са којом највећи проценат ученика показује неодлучност (25\%), али потом следе они који се у потпуности слажу са наведеним (24\%). Мишљења ученика су подељена и у вези са тврдњом Садржаји из ликовне културе ми помажу да препознам лепоmу у различитим предметима (највећи број ученика се слаже (24\%), а нешто мањи проценат је неодлучних (21.2\%), следе они који се не слажу $(20.2 \%)$ и уопште не слажу (19.2\%), а најмање је оних који се потпуно слажу (15.4\%)). 
Половина ученика не сматра да у сваком делу препозна „поруку“ коју је сликар желео да пренесе (26\% са одговором уопште се не слажем; 24\% са одговором не слажем се), а неодлучних је $26.9 \%$.

Ученици препознају неопходност часова ликовне културе и посебност уметничких дела, али њихова подељеност у мишљењима и неодлучност у вези са преосталим тврдњама указује на то да су естетске способности карактеристичне за поједине ученике, те да ови садржаји не подстичу њихов развој у довољној мери. Узрок добијених резултата може бити то што се настава ликовне културе у пракси образовног система у нашој земљи обично своди на цртање и сликање, које је је јако често слободног карактера. У таквим условима, без упућивања ученика на препознавање естетских елемената, без подстицања њихових естетских осећања и естетске осетљивости, не могу се развити ни њихове естетске способности. Поред тога, за развој естетских способности важна је сарадња са културним установама, попут музеја и галерија. У вези са тиме, Кушчевић, Брајчић и Мишурац Зорица (2009) сматрају да би сарадња са музејима требало да буде предвиђена наставним планом и програмом, чиме би се остварило њено системско спровођење. Тако би се међу ученицима развила потреба да и касније, када заврше школовање, наставе да посећују музеје, а развила би се и њихова свест о културној баштини.

Табела 7. Разлике у перцепцијама садржаја из ликовне културе из угла ученика

\begin{tabular}{|c|c|c|c|c|c|c|}
\hline & Разред & $\mathbf{M}$ & SD & t-test & df & $\mathbf{p}$ \\
\hline Часови ликовне културе & 7. и 8. раз. & 2.96 & 1.36 & & & \\
\hline $\begin{array}{l}\text { ме мотивишу да стварам } \\
\text { сопствена уметничка дела }\end{array}$ & 1. и 2. год. & 2.27 & 1.40 & 2.60 & 102 & .01 \\
\hline $\begin{array}{l}\text { Садржаји из ликовне културе } \\
\text { ми помажу да препознам } \\
\text { лепоту у различитим } \\
\text { предметима }\end{array}$ & 7. и 8. раз. & 3.38 & 1.30 & 3.33 & 102 & .00 \\
\hline
\end{tabular}

Израчунавањем t-теста утврђено је постојање статистички значајне разлике у ставовима ученика с обзиром на разред код две тврдње. У случају тврдње Часови ликовне културе ме мотивишу да стварам сопствена уметничка дела $(\mathrm{p}=.01 ; \mathrm{p}<.05)$ ставови ученика 7. и 8 . разреда су ближи одговору нити се слажем нити се не слажем $(\mathrm{M}=2.96)$, док су ученици 1. и 2. године претежно одговарали са не слажем се (M=2.27). Код друге тврдње, Садржаји из ликовне културе ми помажу да препознам лепоту у различитим предметима $(\mathrm{p}=.00$; $\mathrm{p}<.05)$ ситуација је иста, с обзиром на то да је $\mathrm{M}=3.38$ за ученике 7. и 8. разреда и $\mathrm{M}=2.54$ за ученике 1. и 2. године. Узрок добијене разлике може се тражити у самој организацији наставе ликовне културе у основној, односно средњој школи. Наставу ликовне културе у средњој школи карактерише усвајање сложенијих сазнања из области ликовне културе, учење о историји уметности, сликарима, њиховим делима, ликовним техникама и др., док наставу ликовне културе у основној школи карактерише веће присуство креативности, па и подстицаји за 
стварање уметничких дела за учествовање на изложбама и такмичењима, али и за украшавање ентеријера школе.

Представљени резултати сведоче о томе да је развој естетских способности ученика у школи неуједначен што је у складу са налазима истраживања ауторке Бојовић (2010). Такође, добијени резултати показују да ученици имају развијену способност препознавања (опажања) лепог, али не и способности доживљавања и стварања лепог, док истраживање ауторке Бојовић показује да се способности опажања и стварања лепог мање подстичу, те да ученици имају развијену способност доживљавања лепог.

\section{Закључак}

Педагогија, као наука о васпитању самој проблематици васпитања прилази целовито, обухватајући морално, интелектуално, физичко, радно и естетско васпитање. За целовит и хармоничан развој личности, неопходно је посветити пажњу развоју способности у свим овим сферама. Међутим, у школском систему нагласак се најчешће ставља на интелектуално и физичко васпитање, док су преостале врсте васпитања маргинализоване, и, као да се очекује да ће ученик у овим областима самостално развити своје способности. Фокус нашег истраживања је усмерен на естетско васпитање, односно на утврђивање да ли садржаји из књижевности, музичке културе и ликовне културе утичу на развој естетских способности ученика (способност за препознавање, доживљавање и стварање „лепог“).

Добијени резултати показују да ученици препознају естетске елементе у садржајима из књижевности, музичке и ликовне културе, с обзиром на то да увиђају да књижевна дела у себи носе одређене поруке, препознају разлику у музичким композицијама које се обрађују на часовима музичке културе и посебност сваког уметничког дела увиђајући притом неопходност часова ликовне културе за живот. Међутим, када је реч о способностима доживљавања и стварања лепог, ученици су показали неодлучност и подељеност у мишљењима што наводи на закључак да су ове способности развијене тек код појединих ученика. Ученици немају посебан дожсивљај у сусрету са естетским елементима, а садржаји из књижевности, ликовне и музичке културе их нису мотивисали да стварају естетска дела, односно нису код њих развили способност преношења лепог у свакодневни живот. То значи да се естетске способности ученика у школи не развијају уједначено: ученици имају способност препознавања лепог, али не и способности доживљавања и стварања лепог. Остаје отворено питање да ли су садржаји који се обрађују у школи неадекватни, или се можда не придаје довољно значаја развоју естетских способности уз став да оне нису значајне или да ће их ученик развити самостално, без подстицања.

Наша препорука је да се школа повеже са културним установама које својим уметничким садржајима могу умногоме да допринесу развоју естетских способности ученика. Истакнути књижевници, сликари, музичари могу се ангажовати као гостујући предавачи у оквиру наставе из књижевности, ликовне и музичке културе, те својим искуством и личним примером утицати на буђење естетске осетљи- 
вости и естетских доживљаја код ученика и самим тим их мотивисати на стварање естетских дела. Такође, наставник мора активније извршавати задатке у области естетског васпитања ученика, јер није довољно пред ученике ставити садржаје са естетским елементима и очекивати да ће они, самостално, без подстицања, развити своје естетске способности. Осим тога, естетско васпитање не сме бити маргинализовано. Неопходно је посветити већу пажњу естетици, као веома важној за живот једног човека са настојањем да одговор на питање да ли школа води рачуна о развоју естетских спососбности ученика буде потврдан. Могућности за естетски развој ученика су на дохват руке, само их је потребно искористити.

\section{Literatura}

Bojović, Ž. (2010). Funkcionalnost udžbeničkog sadržaja u razvoju estetske kulture učenika. Pedagoška stvarnost, 3(4), 239-256.

Denac, O. (2014). The Significance and Role of Aesthetic Education in Schooling. Creative Education, 5, 1714-1719.

Đorđević, B. (2008). Muzička umetnost kao sredstvo estetskog vaspitanja u razrednoj nastavi. Norma, 13(3), 133-148.

Đorđević, J. i Potkonjak, N. (1990). Pedagogija. Beograd: Naučna knjiga.

Đorđević, M. i Ničković, R. (1991). Pedagogija. Niš: Prosveta.

Kostov, B. (2013). On Beauty and the Beautiful in Aesthetic Education. International Journal of Cognitive Research in science, engineering and education, 1(1). Retrieved (20.05.2018.) from https://dialnet.unirioja.es/descarga/articulo/4909314.pdf

Kuščević, D., Brajčić, M. i Mišurac Zorica, I. (2009). Stavovi učenika osmih razreda osnovne škole o nastavnom predmetu likovna kultura. Školski vjesnik, 58(2), 189-198.

Milutinović, M. Ž. (2015). Aktuelni problemi likovnog vaspitanja na osnovu analize nastavnih programa u srednjim školama. Godišnjak fakulteta za kulturu i medije, 7(7), 579-588.

Nastavni programi za svaku školsku godinu osnovnog obrazovanja i vaspitanja. Preuzeto (20.05.2018.) sa sajta http://www.cerez.org.rs/dokumenta/

Nilüfer Süzen, H. (2013). Language and Interpretation of Aesthetics in Art Education, European Journal of Research on Education, Special Issue: Art in Education, 33-37.

Pejaković, S. (2016). Značaj i mogućnost suvremenog pristupa estetskom odgoju. Acta Iadertina, 13(1), 65-75.

Pilav, S. (2016). A Study on the Aesthetic Value of Texts in Turkish Language Textbooks. Journal of Education and Training Studies, 4(12), 126-135.

Plummeridge, C. (1999). Aesthetic Education and the Practice of Music Teaching. British Journal of Music Education, 16(2), 115-122.

Ristić, B. S. (2007). Problemi odnosa estetskog i pedagoškog u literaturi za decu i omladinu. Norma, 12(2-3), 71-79.

Rojko, P. (2012). Metodika nastave glazbe. Teorijsko-tematski aspekti. Preuzeto (04.04.2018) sa sajta: https://bib.irb.hr/datoteka/566005.ROJKO_Metodika_ 
nastave_glazbe._Teorijsko_tematski_aspekti.pdf

Senjan, I. (2017). Nastava glazbe u hrvatskim općeobrazovnim srednjim školama. Metodički ogledi, 24(1), 31-72.

Stevanović, J. i Dimitrijević, M. (2013). Podsticanje inicijative, saradnje i stvaralaštva u nastavi srpskog jezika i književnosti. Zbornik instituta za pedagoška istraživanja, 45(2), 381-403.

Stojanović, B. (2012). Razvoj emocionalnih i estetskih kompetencija učenika kroz umetnost reči. Pedagogija, 1(12), 113-126.

Suzić, N. (2005). Pedagogija za XXI vijek. Banja Luka: TT-Centar.

Trnavac, N. i Đorđević, J. (1998). Pedagogija. Beograd: Naučna knjiga.

Žunić, D. (2008): Vesela estetika. Beograd: Altera.

\title{
LITERATURE, MUSIC AND ARTS AS FACTORS OF STUDENTS' AESTHETIC COMPETENCES DEVELOPMENT-TRANSVERSAL RESEARCH
}

\author{
Jelena Maksimović, Jelena Osmanović, Tamara Vukić \\ University of Niš, Faculty of Philosophy in Niš, Department of Pedagogy
}

\begin{abstract}
Aesthetic competences include the recognition, the experiencing and the creation of beauty, whereas the development of students' aesthetic competences is an important task that schools ought to accomplish since those competences enable a fulfilled life of each individual, and help humanizing their natures, and expressing their emotions and inner feelings. The possibilities for the development of students' aesthetic competences based on the subject contents including literature, music and arts have been presented in this paper. In addition, the results of the research aimed at finding out how the students perceive these contents i.e. whether these contents contribute to the development of their aesthetic competences have also been presented. The research involved 104 students from the city of Knjaževac. The results have shown that the students have developed the competence to recognize aesthetic elements. When it comes to the students' competences to experience and to create ,the beautiful", the results have shown that the literature, music and arts contents do not stimulate aesthetic feelings and experiences, nor the need of transferng the aesthetic elements into one's everyday life. In other words, only some students have all three competences: recognition, experiencing and creation of ,the beautiful“.
\end{abstract}

Key words: aesthetic education, students' aesthetic competences, literature, music, arts

\section{Citiranje članka:}

Maksimović, J., Osmanović, J. i Vukić, T. (2018). Književnost, muzička i likovna kultura u funkciji razvoja estetskih sposobnosti učenika - transferzalno istraživanje. Godišnjak za pedagogiju, 3(2), 31-44 